\section{U.S. National Recovery Act Oil Code}

THE American petroleum industry has adopted a code of fair competition, which aims at adequate and economic supplies of petroleum and its products by eradicating such abuses in all branches of the industry as may cause fluctuations in supply inconsistent with actual demand. It further seeks to conserve and prevent wastage of natural resources; to rationalise internal organisation by standardising wages and improving labour conditions; and to give practical effect to the policy implied by the National Industrial Recovery Act. Production is to be balanced so far as possible against demand, as estimated by federal authority, allocated equitably among the several States by the said authority, and finally sub. divided by State authorities into pool, lease and/or well quotas. Similarly, to prevent unbalanced accumulation of gasoline inventories in any part of the country, and to facilitate equitable access of refiners to the permissible supply of crude oil, the country is to be divided into refining districts by a federal agency authorised to declare proper ratios between inventories and sales of gasoline in the respective districts.

MARketing conditions imposed by the oil code summarily enforce the posting of prices by retailers and wholesalers of all grades of petroleum; they will prevent deviation from such posted prices by rebates. allowances, etc. and establish a fixed schedule of credit pertaining to the whole industry. In addition, a detailed schedule of equipment prices to be used as a basis of purchase or sale between oil companies is appended. The terms of the code are to be enforced and the administrative duties carried out by a committee representing the industry and by a federal agency to be designated by the President. The federal agency will be responsible for estimates of petroleum demand and for recommendations re quotas, allocations and inventories as stated above. The industry as a whole is under obligation to supply such necessary technical data and statistical reports as may be required for the effective administration of the code.

IT is as yet early days to appreciate the full force of this unique recovery act in the United States and its influence on the economic and social life of the community as a whole, and already in other industries there are signs that its immediate results have not been up to the optimistic anticipations of its sponsors. As applied to the oil industry, it is clearly undergoing a most acid test, since no industry in the United States has suffered so much from lack of co-ordinating influences. Quite apart from the economics involved, obedience to the code must inevitably bring with it drastic changes in the technical control of the industry, particularly as it affects drilling, production, conservation of reserves and refinery practice. If it succeeds, its repercussions will be world-wide, for America having put her house of petroleum in order, it will be impossible for other countries not to come into line. The code as it stands is the nearest approach to State control of a key industry which has ever been framed in the United States.

\section{The Rubber Research Association}

THe present plight of the Research Association of British Rubber Manufacturers is a deplorable example of the results caused by an absence of any stabilised policy of financing industrial research. This Association was established in 1920, and has hitherto been maintained by voluntary subscriptions from individual manufacturing concerns, and by grants from the Department of Scientific and Industrial Research, out of the $£ 1,000,000$ fund set aside by Parliament in 1917 for industrial research in general. The Association has performed work of the utmost value to the community and to the industry as a whole. That work has had the effect of making the smaller units in the industry much more efficient, and it is to be feared that the resulting increase of efficiency in the smaller units has created a feeling of apprehension in some of the larger units, accompanied by an unwillingness-and even point blank refusal-to contribute further. Thus the value of the Association's work has contributed to its undoing. An endeavour was made by friends in the House of Commons to place its finances on a stable basis by promoting the Rubber Industry Bill, which provided for a small compulsory levy on all imports of raw rubber. After a troubled history the Bill was adopted by the Government last May : but later the Government dropped it, apparently in consequence of the opposition raised by some elements of the industry.

IT would be a national calamity if the valuable work of the Rubber Research Association were allowed to be stopped for want of adequate financial support. The Government has now made an offer to the Association to contribute on what may roughly be described as a pound per pound basis, that is, to contribute as much money as the Association can raise by voluntary contributions from the industry. At best, this can only leave the Association with a fluctuating income; and a fluctuating income is precisely the type of revenue that makes systematic planning ahead impossible. Anything short of stabilised revenue inevitably results in wasteful expenditure (as in the case of the Forestry Commission). It is applying rule of thumb methods to scientific work; and thus things move in a vicious circle, bringing about a negation of true economy. However, the last word has not been said on this subject. The Association is receiving powerful backing from influential quarters. It is understood that the Association of Chambers of Commerce, the British Science Guild, and the Association of Scientific Workers are taking joint and individual steps, with the view of securing more adequate financial support to enable the Research Association to tide over its period of difficulties, and to make possible the retention of its experienced technical and scientific staff. 